\title{
Pembelajaran Daring: Ancaman Perusahaan EdTech Pada Sekolah Ditengah Pandemi Covid-19
}

\author{
Atyanta Nika Rumaksari \\ atyanta.rumaksari@uksw.edu \\ Fakultas Teknik Elektronika dan Komputer Universitas Kristen Satya Wacana
}

Digital Learning: The Threat Of EdTech Firm To School Amid A Covid-19's Pandemic

\begin{abstract}
Covid-19 forces the traditional classroom learning method to go online; while teachers nowadays struggle to adapt to this new technology, the EdTech firm's market is increasing. That 44 startups were categorized as Unicorn in 2020. Rather than just referring to the analysis of EdTech's functions that help schools conventionally, this study also looks at the theory of economic-based interaction between education-based organizations that threaten schools' meaning and function that shift during this pandemic to online. Based on this premise, we can identify the features of EdTech, which overlap with conventional schools. Our method is conducting Descriptive Analysis based on observed data derived from validated formal research and put them into three dimensional business model patterns to get evidence of the organization's strategic or tactical operations. This research aims to address whether the emerging of EdTech firms becomes a threat to traditional schools. This work also finds the core value, which drives student's motivation toward learning outcomes in Indonesia. Based on the research, superior ICT technology adaptation plays an essential key in educational activities. It means that EdTech can provide dependence on schools which not yet comply with these features so that when they had cooperation, EdTech can direct or even changing the school's original values. This cooperation dependency can challenge the school's operation cost, increasing the risk of supply and management, involving consumer-related decision-making that always benefited EdTech rather than schools.
\end{abstract}

Keywords: EdTech, Self-efficacy, Teacher Education, Enhanced Digital Learning, Impact of Pandemic Covid-19 in Education

Received date: 6 November $2020 \quad$ Revised date: 18 Januari $2021 \quad$ Accepted date: 19 Januari 2021

\section{INTRODUCTION}

Covid-19's pandemic made traditional classroom learning method upside-down because educational institutions are forced to change their classroom learning method into an online-based learning method similar to distance-based e-learning apps such as Coursera, Ruang Guru, Aksara Maya, Dana Didik, or Udacity. Teachers must adapt to new skills as content creators, including explaining the knowledge interestingly, creating animation editing software, outstanding oral communication skill, digital awareness, video editing, and social media presence (Amalia \& Satvikadewi, 2020). Even though content creator does not necessarily have a role to be a teacher, nowadays, Internet and Communication Technology brought a new wave of culture that needs the teacher to be adapted. The emerging of "digital production" makes massive information that each of them is being disseminated rapidly. Thus, the content creator needs to follow this pattern by knowing when to produce the content wisely.

There are much reluctance of teachers while adapting to this condition because they found that digital literacy is a core component that needs to be familiar. This issue is well addressed by the research of Lankshear that argue rather than presuming digital literacy as a unitary phenomenon that generates an autonomous model that being perceived by coded text message that has tendency only in cognitive competency without implying about digital content which able to have immediate interaction, behave, and feedback (Lankshear \& Knobel, 2006). It is clear. Therefore, that technology adoption is associated with paradigm reposition. The adaptability of a teacher is a mandatory requirement that must be done 
during this Covid-19's pandemic. This argument is supported by two basic premises: the imposition of government regulations that prohibit physical proximity and the threat of online service provider educational sites (EdTech) that have more attractive and promising content.

Likewise, this research's primary goal is to determine schools' challenges because of the rapidly growing EdTech ICT-based industry.

Consequently, this article will provide analysis of feature EdTech which is being shown from its features, the business strategy of EdTech industry in order to marketize the product, government regulation related with emerging EdTech, and how big is the overlapping EdTech's role to School that is a view as a threat to School.

\section{LITERATURE REVIEW}

While countries are struggling from Covid-19's pandemic nowadays, the result is moving forward and picking the radical impact on our civilization. Since the world announces that Covid-19 is very dangerous on December 13, 2019, via the World Health Organization (WHO) China Country Office, this message relay will soon spread throughout the mass media. By the first week of January 2020, WHO set up Incident Management Support Team (IMST), a subdivision of WHO which layered in three levels: headquarters, regional headquarters, and country level. Officially on January 5, 2020, WHO brings forth the first disease epidemic news (WHO, 2020b). Based on the daily world cases we found that from July 22 to September 11 the worldwide trend of Covid-19 is not yet drastically decreasing, but somehow it exists and creates a periodic pattern which some expert says it formed just like rebound wave pattern (Girona, 2020)(WHO, 2020a). Experts try to predict the end of the pandemic using a primary method, but they found it challenging to address the prediction of Covid-19 spreading (Kuhl, 2020; Li et al., 2020). The government then uses the prediction model to prevent and overcome Covid-19 impact (Hutson, 2020; Roda et al., 2020).

Research by Annas suggests that vaccines' importance plays a vital role in Indonesia's epidemic Covid causes (Annas et al., 2020). The finding stated that there is a time delay before the epidemic curve is decreasing. This time is very crucial because it can affect the success of government policies in tackling Covid-19. The model shows that when a suspected patient is isolated within 14 days, the number of Exposed populations will gain the smallest number, around 29,000 people. Within the period of isolation, the government can carry out the plan to grind Covid-19's pandemic.

It began on February 4, 2020. Ministry of Health declares the response of the novel of Covid19 (HK.01.07/MENKES/104/2020). Since the President of Indonesia's actions, he created Government Regulation No 21/2020 about Huge-scale restriction for accelerating Covid-19 extermination (Djalante et al., 2020). All the infrastructures for carrying out this strategy are parallel being prepared and enforced. One of them is the education sector. As a result, the national economic growth condition in the second quarter of 2020 contracted $5.32 \%$ (YoY) versus the first quarter of 2020 positive $2.83 \%$ (YoY). All sectors of the economy contracted in the second quarter of 2020, except for Information and Communication; this greater uptake of digital media responded to the Work-From-Home (WFH) and School From Home (SFH) protocols. Also, the government is trying to enhance the agricultural sector's result, which is supported by the ongoing harvest season (Bank Indonesia, 2020).

Minister of Education response it issues via Ministerial Decree No. 3 yr. 2020 and 36962/MPK. A/HK/2020 about prevention of Covid-19 by implementing Work from Home (WFH) activities. An online learning system, then being forcefully implemented throughout Indonesia. Redefining the onlinebased school curriculum is needed as fast as possible in the response of the decree. In response to this demand, the School is being demanded to create an online education platform that needs to be accessible, free, and easy to understand regardless of smart-device compatibility. When the School is trying to improve its online learning platform, the EdTech (Education Technology apps) gets a golden opportunity to increase its income by advertising to help students learn to attract more customers. The turning point of educational technology was based on the Bologna declaration in 1999. It gives information technology opportunity as a foundation factor to deliver the educational value toward students to become more robust and adaptive. This finding is based on Del Campo's research in that time, that the student learning curve is proven to be decline than manual way. It happens because somehow, using the cutting edge technology of ICT the student often get distracted easily by surrounding than learning in class using the manual teaching procedure (idiom: chalk and board way) 
(del Campo et al., 2012). The second finding is about the prediction that near-far-future from the written article (2012), virtual meeting scenario is happening, and the tube-like show was emerging, and it may become the future business model of the educational system.

Understandably, a view of rising ICT that influences more excellent, broader, and more resilient internet coverage will become the backbone of the Internet of Things (IoT) technology, which now leads to Industry 4.0. Thus, social media's emerging role is to develop the genuine concept of virtual and augmented reality (Abad-Segura et al., 2020). Based on this philosophy, that person can be present anywhere without considering a physical border will make the concept of a virtual classroom (meeting) (Jorgenson \& Vu, 2016). The growth of ICT made this technology is increasingly approachable and leads to affordability. The pandemic is making the happening of the Massive Open Online Course (MOOC) market more attractive. The market growth 2020-2024 is predicted to grow over 29\% worldwide. The existing top player of this player, such as Coursera Inc, edX Inc, Udacity Inc, FutureLearn Ltd, will get more benefit from this opportunity (MarketWatch.com, 2020).

The complexity of theory is used with critical thinking as the primary material for creating an epistemological critique of learning outcomes. This method aims to understand the driver of student learning. It starts from how the student interprets the knowledge as an interpretative framework in a learning outcome, and it will be enhanced by two additional Factor, which is the goal of the educational institution and student self-motivation. Those three factors can be used as student learning parameters (Anugraheni, 2019; Erikson \& Erikson, 2019). However, the rise of EdTech in Indonesia will create higher learning outcomes, but the argument of World Bank article on the readiness of the Indonesian government implementing EdTech ICT based on the educational system (World Bank, 2020).

\section{METHOD}

In this study, the aim is to explain the Factor that made schools business process is threatened. The first paradigm that needs to be concerned is that education institutions, regardless of whether they have a form of the national or public sector, are profit-oriented. The second paradigm that plays an integral role in the first paradigm is social value and knowledge as a utility value to bring forward the nation, as contained in the Indonesian general mission of sustainable development growth.

In order to achieve the result, we perform qualitative analysis using study primer literature. Figure 1 shows the guidelines. This figure shows that the research needs to address three factor dimensions to understand EdTech and School's behavioral action in terms of the business process. They are Factors that made the business model exists, Future challenge, and Learning Method. The pedagogical aspect will then be carried out by finalization after applying the method. According to the research goal, the pedagogical aspect plays an essential role in analyzing the effective learning method.

\begin{tabular}{|c|c|c|c|}
\hline \multicolumn{2}{|c|}{ Review of Business Model EdTech. } & \multicolumn{2}{|c|}{ School Business Model } \\
\hline $\begin{array}{l}\text { Factor that made } \\
\text { business model exist. } \\
\text { 1. Need or demand } \\
\text { from the market } \\
\text { (market driven) } \\
\text { 2. Pandemic influence } \\
\text { that force country to be } \\
\text { "New Normal" physical } \\
\text { distancing. } \\
\text { 3. Certification that } \\
\text { being view as } \\
\text { secondary/auxiliaries }\end{array}$ & $\begin{array}{l}\text { Future Challenge } \\
\text { 1. Pandemic cycle is } \\
\text { unpredictable. } \\
\text { Learning Method } \\
\text { 1. Full Online based. } \\
\text { 2. Video is being } \\
\text { packed attractively }\end{array}$ & $\begin{array}{l}\text { Factor that made } \\
\text { business model exist. } \\
\text { 1. Need or demand } \\
\text { from the market } \\
\text { (market driven) } \\
\text { 2. Pandemic influence } \\
\text { that force country to be } \\
\text { "New Normal" physical } \\
\text { distancing. } \\
\text { 3. High belief of the } \\
\text { school certification. }\end{array}$ & $\begin{array}{l}\text { Future Challenge } \\
\text { 1. Pandemic cycle is } \\
\text { unpredictable. } \\
\text { Learning Method } \\
\text { 1. Full Online based. } \\
\text { 2. Semi online } \\
\text { can be switch to } \\
\text { classroom model when } \\
\text { physical distancing is } \\
\text { off. }\end{array}$ \\
\hline $\begin{array}{l}\text { Marke } \\
\text { 1. Foct } \\
\text { 2. Stru } \\
\text { 3. Easy } \\
\text { 4. Out } \\
\text { 5. Phy }\end{array}$ & $\begin{array}{l}\text { eds: } \\
\text { earning about major te } \\
\text { al belief that highly edn } \\
\text { implement } \\
\text { e based education syste } \\
\text { Distancing. }\end{array}$ & $\begin{array}{l}\text { subject. } \\
\text { eople is tend to have bett }\end{array}$ & \\
\hline
\end{tabular}

Figure 1. The Methodology 
This research uses an in-depth literature review by extracting relevant information to understand EdTech and School's growth trajectory as a comparison that was impacted by the Covid-19's pandemic. The research also contains World Bank Group datasets that play an essential role in becoming primary data sources (World Bank, 2020).

\section{RESULTS AND DISCUSSION}

\section{EdTech Global Market Research}

Based on toptal.com, a market research analyst portal, it can be found that the premise of Online learning is accelerated in 2020; therefore, it can be said like a year of the MOOC. Therefore, from the argument, it can infer that in the year 2020, EduTech participates in the Renaissance phenomenon. Southwick also infers that the rising business opportunity will result in a rise in profit sharing and competition. Based on Porter's five forces theory, when the barrier to entry is low, the competition will increase, and when market share is starting to grow, fierce competition will exist (Porter, 1979). This theory can be proven by four macro trends in the three past years: population growth in developing countries, the rise of digitalization technology, the demand of EdTech tools and services is increasing, and Industry's assessment and tutorial prefer to be online-based-content (Corporate training). The Metaari Free Annual Whitepaper on Global EdTech investment says that the massive investment is from 2019, which concentrated on EdTech unicorn. Unicorn is a company that valued greater than billion-dollar valuation. In 2019, 44 companies are Unicorn, and 33 of 44 are from 2018. A combination of those 44 were obtained 8.56 billion, or $45.8 \%$ of the Total Global Investment (Adkins, 2020).

\section{EdTech in Indonesia}

Indonesia is one of the leading markets in EdTech industry when it is being viewed from market number. However, several factors need to be considered by investors to put the investment in Indonesia. The student learning method is the one factor that is very important because it covers students who can afford the price. Secondly, the expandable market view EdTech will be lowered to kindergarten since the study proves that kindergarten's computer proficiency can be categorized high. Addressing the resilience of some teachers who do not want to improve themselves, unavoidably, the School is working together with EdTech apps to provide tutor-class suitable to the current conditions. This combination will lead to momentary synergy to withstand pandemic.

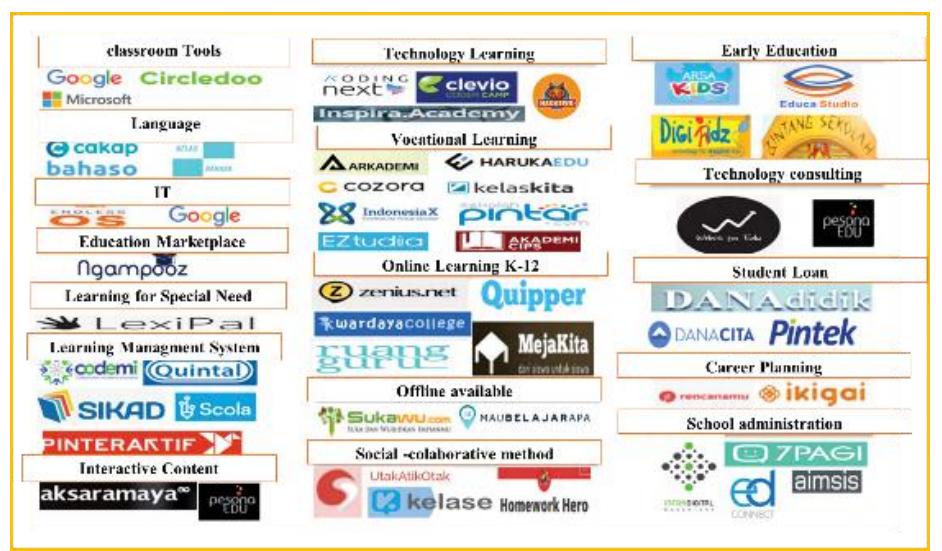

Figure 2. EdTech Firms in Indonesia (World Bank, 2020).

Addressing the issue of lacking ICT infrastructure, the government, Pustekkom, is responsible for building ICT infrastructure throughout Indonesia. Not only build infrastructure, but it also provides e-reporting, e-management, e-service to individuals or organization. It develops a system that ensures the e-learning knowledge can be successfully transferred to students to build a positive learning curve (Pustekkom Kemendikbud, 2020). Based on the World Bank Forum research, EdTech firms in Indonesia majority have more than one service. Therefore, the firm can holistically give extra service/benefit to support their target fully. A lot of EdTech company has administration and management service for educator or School, such as Learning Management System (30\%), Online courses (27\%) and Vocational Online Learning (VOL) 25\%. It is evident from the data that EdTech company will have a board target from student to the institution. Figure 2 shows us the wholeness of 
EdTech in Indonesia. It covers from product and service that is being clustered offered to the student for tutorial and test preparation until career development planning. Each of the companies ( $40 \%$ of them appx.) does not focus in career development/administration oriented but takes the one focus on technical skills for an example: programming language, financing skills, science, and language.

\section{The Threat of EdTech Firm}

Based on the research of Anugrahana, it can be inferred that most teachers in Bantul Indonesia are not yet familiar with complex and sophisticated platforms such as zoom, GoogleMeet, etc. They were reluctant to choose it because of its complexity. Therefore, they prefer to choose Whatsapp or social media messaging platforms (Anugrahana, 2020). Because of the lack of action, the educator's role can be threatened to be replaced by EdTech firm. Figure 2 shows that EdTech firm provides not only ICT infrastructure but also a tutor who deliver the knowledge.

EdTech is active in acquiring a teacher or lecturer as a firm's professional mentor. It is not easy to maintain objectivity to create a learning system that guarantees students to overcome the replacement test/entrance test in (for example) a particular University. This issue (K-12) is quite dangerous because Educational institutions can lose their integrity and assessment standards to achieve standard student intake to comply with an institution's core value.

Online learning aims to provide high-quality education anywhere and anytime. When the student has an intention to follow the procedure, this system is beneficial to do multi-tasking activities, help those who have a barrier because of hospitalization, having phobia to the school environment, single parent, have been expelled or currently joining public community services (Gilbert, 2015). The demand for online learning is about self-directed how-to activities with the seed of self-control. The center of an online learning system is in oneself. Unlike an offline learning system (in class), that somehow depends on the synergy between teacher and student. Teachers can do direction or monitor the task quicker because they are face-to-face with the student. Secondly, when there is a failure of personal learning, the teacher can respond before the problem is getting more complicated. Thirdly, the problem being faced this day is about the network security issue. The provider cannot guarantee safety $100 \%$ malware-free. Thus we may face obstacles regarding data theft, trojan, virus. Since the learning platform is too complex to be maintained by an educational institution (School), School, if it wants to create a platform by itself, chooses to invest in ICT. In contrast, the cost of ICT investment is not economical.

The role of an educational institution is rooted deeply in Indonesia. Therefore, whatever online platform is chosen, the brand of formal education is the leading choice. The success factor of online learning lies in self-efficacy. Self-efficacy is a stimulant of pedagogical creativity in order to achieve effectiveness in teaching-learning (Oddone, 2016). Oddone and Alqurashi's study proves that in ICT, teaching-learning activities' success factor lies in self-efficacy as a foundation (Alqurashi, 2016; Oddone, 2016). Based on Bandura, self-efficacy is being made (cultivated) systematically to strengthen the inner-self, while the self-efficacy is well maintained, and autonomous self-confidence is increasing (Bandura, 2002). The influence of others and the surrounding environment are forcing educational institutions to pass through the obstacles. How a person is willing to pay for preserve while against the problem/obstacles determines the level of performance, and the primary ingredient of preserving is belief or self-efficacy.

From the passage, we can conclude that, even though EdTech firms can influence students on learning activities, it only impacts the medium and the technical action of providing teaching-learning, regardless of who the provider is. On the other hand, as an educational institution, the school chooses to do blended learning, which touches the core of helping students build their self-efficacy. By keeping in touch as a family can maintain a sense of ownership in an organization. Numerous school activities shape the emotional quotient, such as arts, music, sport-club, which students can work out. Thus, an educational institution's role in maintaining professional skill and humanistic skills is critical to bring better success factors.

\section{CONCLUSION AND RECOMMENDATION}

Since it opens the new opportunity to gain capital in learning method, educational institution obtains swift paradigm, from offline-based oriented to online-based oriented. Teachers and institutions need to welcome this adaptation in order to survive in this marketplace. Our research found that 
conventional schools are being threatened by EdTech because these firms have superior bargaining positions toward technology than fundamental schools. It means that there is a possibility for EdTech provides dependence on schools so that they can direct or even changing the school's original values. The role of EdTech needs further investigation because ICT has a vital role in bringing the technology of e-learning to exist.

The critical success factors of learning outcomes lie in how students build self-efficacy. It is a belief that use as the foundation of student motivation in overcoming obstacles while learning. This research also found that school branding is still playing a vital role in the educational institution than EdTech. They only act as auxiliary and support in providing ICT based learning system.

This finding only addresses one self-efficacy factor. There are many other factors influencing motivation that yet to be described. Hopefully, another researcher can continue this work.

\section{REFFERENCES}

Abad-Segura, E., González-Zamar, M. D., Luque-de la Rosa, A., \& Cevallos, M. B. M. (2020). Sustainability of educational technologies: An approach to augmented reality research. Sustainability (Switzerland), 12(10). https://doi.org/10.3390/su12104091

Adkins, S. (2020). 2019 Global Edtech Investments Reach a Staggering \$18.66 Billion. Https://Www.Prweb.Com/.

https://www.prweb.com/releases/2019_global_edtech_investments_reach_a_staggering_18_6 6_billion/prweb16814926.htm

Alqurashi, E. (2016). Self-Efficacy In Online Learning Environments: A Literature Review. Contemporary Issues in Education Research (CIER), 9(1), 45-52. https://doi.org/10.19030/cier.v9i1.9549

Amalia, T. W., \& Satvikadewi, A. A. I. P. (2020). Personal Branding Content Creator Arif Muhammad (Analisis Visual pada Akun Youtube @Arif Muhammad). Representamen, 6(01). https://doi.org/10.30996/representamen.v6i01.3519

Annas, S., Isbar Pratama, M., Rifandi, M., Sanusi, W., \& Side, S. (2020). Stability analysis and numerical simulation of SEIR model for Pandemic COVID-19 spread in Indonesia. Chaos, Solitons and Fractals, 139, 110072. https://doi.org/10.1016/j.chaos.2020.110072

Anugrahana, A. (2020). Hambatan, Solusi dan Harapan : Pembelajaran Daring Selama Masa Pandemi Covid-19 Oleh Guru Sekolah Dasar. Scholaria: Jurnal Pendidikan Dan Kebudayaan, 10(3), 282-289.

Anugraheni, I. (2019). Analisis Kemampuan Berpikir Kritis Mahasiswa Dalam Menyelesaikan Permasalahan Bilangan Bulat Berbasis Media Realistik. Scholaria: Jurnal Pendidikan Dan Kebudayaan, 9(3), 276-283. https://doi.org/10.24246/j.js.2019.v9.i3.p276-283

Bandura, A. (2002). Encyclopedia of mental health. Choice Reviews Online, 39(08), 39-4322-39-4322. https://doi.org/10.5860/choice.39-4322

Bank Indonesia. (2020). National Economic Growth Impacted by COVID-19 in Q2/2020 - Bank Sentral Republik Indonesia. Government Press Release Bank Indonesia. https://www.bi.go.id/en/iru/government-press-release/Pages/National-Economic-GrowthImpacted-by-COVID-19-in-Q2-2020.aspx

del Campo, J. M., Negro, V., \& Núñez, M. (2012). The History of Technology in Education. A Comparative Study and Forecast. Procedia - Social and Behavioral Sciences, 69(Iceepsy), 1086-1092. https://doi.org/10.1016/j.sbspro.2012.12.036

Djalante, R., Lassa, J., Setiamarga, D., Sudjatma, A., Indrawan, M., Haryanto, B., Mahfud, C., Sinapoy, M. S., Djalante, S., Rafliana, I., Gunawan, L. A., Surtiari, G. A. K., \& Warsilah, H. (2020). Review and analysis of current responses to COVID-19 in Indonesia: Period of January to March 2020. Progress in Disaster Science, 6, 100091. https://doi.org/10.1016/j.pdisas.2020.100091 
Pembelajaran Daring: Ancaman Perusahaan EdTech Pada Sekolah Ditengah Pandemi Covid-19

(Atyanta Nika Rumaksari)

Erikson, M. G., \& Erikson, M. (2019). Learning outcomes and critical thinking-good intentions in conflict. Studies in Higher Education, 44(12), 2293-2303. https://doi.org/10.1080/03075079.2018.1486813

Gilbert, B. (2015). Online Learning: The benefits and challenges. In Education Masters. http://libguides.sjfc.edu/citations.

Girona, T. (2020). Confinement Time Required to Avoid a Quick Rebound of COVID-19: Predictions From a Monte Carlo Stochastic Model. Frontiers in Physics, 8, 186. https://doi.org/10.3389/fphy.2020.00186

Hutson, M. (2020). Why Modeling the Spread of COVID-19 Is So Damn Hard - IEEE Spectrum. IEEE Spectrum. https://spectrum.ieee.org/artificial-intelligence/medical-ai/why-modeling-thespread-of-covid19-is-so-damn-hard

Jorgenson, D. W., \& Vu, K. M. (2016). The ICT revolution, world economic growth, and policy issues. Telecommunications Policy, 40(5), 383-397. https://doi.org/10.1016/j.telpol.2016.01.002

Kuhl, E. (2020). Data-driven modeling of COVID-19-Lessons learned. In Extreme Mechanics Letters (Vol. 40, p. 100921). Elsevier Ltd. https://doi.org/10.1016/j.eml.2020.100921

Lankshear, C., \& Knobel, M. (2006). Digital literacy and digital literacies. Nordic Journal of Digital Literacy, 1(November), 12-24. https://doi.org/10.1108/EL-05-2015-0076

Li, L., Yang, Z., Dang, Z., Meng, C., Huang, J., Meng, H., Wang, D., Chen, G., Zhang, J., Peng, H., \& Shao, Y. (2020). Propagation analysis and prediction of the COVID-19. Infectious Disease Modelling, 5, 282-292. https://doi.org/10.1016/j.idm.2020.03.002

MarketWatch.com. (2020). Massive Open Online Course (MOOC) Market Size 2020 Top countries data Industry Size, Share, Business Growth, Revenue, Trends, Market Demand Penetration and Forecast to By 360 Market Updates - MarketWatch. Press Release. https://www.marketwatch.com/press-release/massive-open-online-course-mooc-market-size2020-top-countries-data-industry-size-share-business-growth-revenue-trends-market-demandpenetration-and-forecast-to-by-360-market-updates-2020-09-11

Oddone, F. (2016). Self-efficacy: A booster for pedagogical innovation. Journal E-Learning and Knowledge Society. Italian e-Learning Journal, 12(3), 51-64. https://doi.org/10.20368/1971$8829 / 1155$

Porter, M. E. (1979). How Competitive Forces Shape Strategy. Hardvard Business Review. https://hbr.org/1979/03/how-competitive-forces-shape-strategy

Pustekkom Kemendikbud. (2020). SimpaTIK - Sistem Informasi Manajemen Pelatihan Berbasis TIK. Https://Simpatik.Belajar.Kemdikbud.Go.Id/. https://simpatik.belajar.kemdikbud.go.id/

Roda, W. C., Varughese, M. B., Han, D., \& Li, M. Y. (2020). Why is it difficult to accurately predict the COVID-19 epidemic? Infectious Disease Modelling, 5, 271-281. https://doi.org/10.1016/j.idm.2020.03.001

WHO. (2020a). Timeline of WHO's response to COVID-19. Who.Int. https://www.who.int/emergencies/diseases/novel-coronavirus-2019/interactivetimeline?gclid=CjwKCAiAv4n9BRA9EiwA30WND-CxfWOnymMUQ5j4FIE_vN63VYVyR62AVTGI5fxJtcFBoUSXmFv_hoC3-kQAvD_BwE\#!

WHO. (2020b). WHO | Pneumonia of unknown cause -www.who.int/csr/don/05-january-2020pneumonia-of-unkown-cause-china/. Who.Int. https://www.who.int/csr/don/05-january-2020pneumonia-of-unkown-cause-china/en/

World Bank. (2020). Edtech in Indonesia - Ready for Take-Off? www.worldbank.org 